\title{
MERCURY SPECIES IN URBAN ATMOSPHERE
}

\author{
J. LU, D. PRETE \& A. AL HEJAMI \\ Department of Chemistry and Biology, Ryerson University, Toronto, Canada
}

\begin{abstract}
Mercury $(\mathrm{Hg})$ in indoor and outdoor air in the city core at various heights above ground, and in indoor and outdoor air was measured in Toronto, the largest city in Canada. For the measurements of gaseous elemental mercury (GEM), a mercury-monitoring system (Tekran Inc., Toronto, Canada) was used. In addition, mercury associated with indoor and outdoor particulate matter in the city and surrounding area was also measured. Mercury in outdoor particulate matter (as total filterable $\mathrm{p}-\mathrm{Hg}$ ) was determined through thermal desorption gold pre-concentration CVAFS. The analysis of mercury in indoor particulate matter (as settled dusts) followed the USEPA Method 1631E and Appendix to Method 1631. The results show:
\end{abstract}

- the higher GEM concentration values in outdoor air were more concentrated in the city core;

- GEM in indoor air was much higher than in outdoor air;

- the GEM values increased with increasing elevation;

- emissions from vehicles and ground surfaces in the city were not the major sources of GEM to the urban atmosphere;

- the concentrations of total filterable $\mathrm{p}-\mathrm{Hg}$ in outdoor air ranged from 20.1 to $63.0 \mathrm{pg} \mathrm{m}^{-3}$ and those for indoor settled dusts ranged from 0.01 to $10.0 \mathrm{mg} \mathrm{kg}^{-1}$.

The findings suggest that mercury used in the indoor environment serves as a source of $\mathrm{Hg}$ to the urban atmosphere.

Keywords: depth profiling, filterable mercury, gaseous elemental mercury, indoor settled dust, Toronto, urban atmosphere.

\section{INTRODUCTION}

Mercury $(\mathrm{Hg})$ is a persistent and highly toxic element [1]. It can be emitted from natural and anthropogenic sources, largely as gaseous elemental mercury (GEM) [2-4]. The atmosphere receives most of the mercury emitted from these sources [4]; thus, it is the major pathway of transporting this toxic element. Elemental $\mathrm{Hg}$ has an atmospheric lifetime of around 1 year [5], and therefore, it is considered a true global pollutant.

Due to its unique physical and chemical properties, $\mathrm{Hg}$ has been widely used in industry (e.g. in electrical equipment and control devices, in the electrolytic preparation of chlorine and alkalis), agriculture (e.g. as pesticides, fungicides and bactericides), dental practices, pharmaceuticals and daily products such as thermometers, barometers, bulbs, batteries, paints and cosmetic products etc. Most of the above-listed processes and uses are concentrated in cities and therefore are the sources of mercury in the environment. Limited studies have indeed shown higher atmospheric mercury in urban areas [6-10], and the concentrations of GEM in urban atmosphere varied with variation of urban structure and height $[3,7,8]$. Our studies showed that local sources which have neither been identified nor reported in the 
Canadian National Pollutant Release Inventory (NPRI) might have contributed to the high levels of atmospheric $\mathrm{Hg}$ in Toronto [11,12].

\section{EXPERIMENTAL}

\subsection{Experimental location}

The experiments were carried out in the city of Toronto (population 2.5 million), Ontario, Canada. The site locations are shown in Fig. 1. According to the NPRI Environment Canada [13], there is no source of $\mathrm{Hg}$ (cut-off level of $5 \mathrm{~kg} \mathrm{yr}^{-1}$ ) in the city area.

\subsection{Instrumental}

Atmospheric GEM was measured along the major streets in the city, using a mercury vapor analyzer (Model 2537A, Tekran Inc., Toronto, Canada). The analyzer has a built-in air pump for air sampling and employs dual gold cartridges, arranged in parallel, for $\mathrm{Hg}$ pre-concentration, allowing for continuous measurements of mercury in the air. After every 2.5-min pre-concentration period, mercury is thermally desorbed from the gold cartridges and determined using cold vapor atomic fluorescence spectrometry (CVAFS). Since the particulate matter in the air stream was removed by a front-end Teflon filter before it entered the analyzer, it is widely accepted that the analyzer measures GEM in the air sample. The analyzer was calibrated automatically through a built-in mercury permeation source every $23 \mathrm{~h}$. The mercury permeation source was verified by manual injection before and after the field campaign. The internal permeation source provided approximately $1 \mathrm{pg} \mathrm{s}-1$ of GEM $(\mathrm{Hg} 0)$ at $50^{\circ} \mathrm{C}$ into a zero-air stream, whereas the manual calibration was done by injecting a known volume of air saturated with mercury vapor at a controlled temperature from a mercury vapor calibration unit (Tekran Inc., model 2505, Toronto). The average detection limit was about $0.1 \mathrm{ng} \mathrm{m}-3$ for GEM.

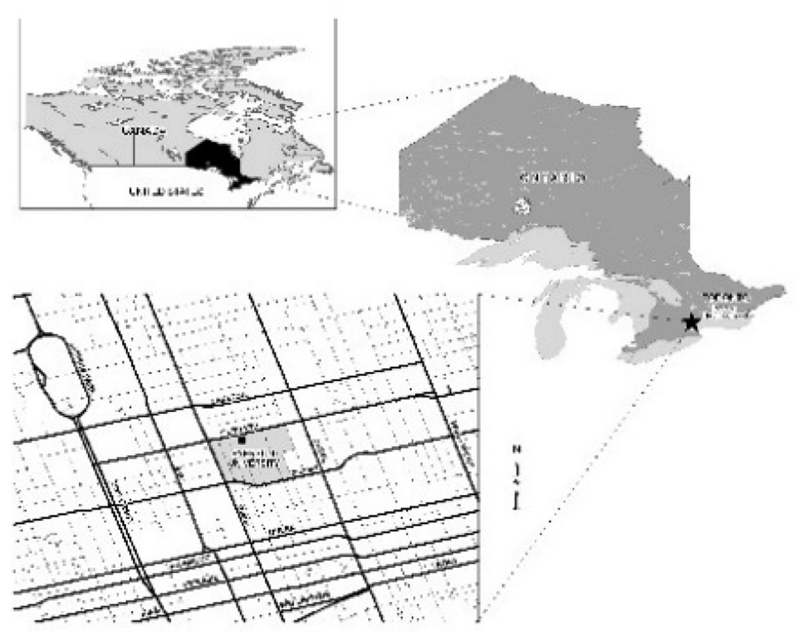

Figure 1: Experimental locations. 


\subsection{Method}

During the street measurement period, the analyzer was installed on board of a minivan with two inlets: one hanging over the windshield using a pole that was held on the rooftop of the van and was about $1.8 \mathrm{~m}$ above ground (i.e. at pedestrian level) and the other was attached to a pole that extended about $4 \mathrm{~m}$ above ground. While driving along the streets and highways, only the 1.8-m inlet was used. A global positioning system (GPS) was used to track the locations of the analyzer. While parked at some of the surface lots, air was sampled from the two inlets in an alternative fashion. A second mercury analyzer, which was a part of the mercury speciation monitoring system, was running on the rooftop of Jorgensen Hall (JOR), Fig. 1, which is $\sim 59 \mathrm{~m}$ above ground. Accordingly, while the van was parked around JOR, GEM was measured from three levels: 1.8, 4 and $59 \mathrm{~m}$ above ground. Rooms with different usage types (e.g. lab and office) were selected for the measurements of GEM in indoor and outdoor air. These rooms are located in the north and east sides of a square-shaped building (Kerr Hall, $160 \mathrm{~m}$ long) with a courtyard in the middle. During the experiments, the pump in the analyzer pulled air in from inside and outside (using Teflon tubing through a window) in an alternating order for each room tested. Mercury in the outdoor filterable particulate matter was determined through thermal desorption gold pre-concentration CVAFS. The analysis of mercury in indoor settled dusts followed USEPA Method 1631E [14] and Appendix to USEPA Method 1631 [15].

\section{RESULTS AND DISCUSSION}

\subsection{Outdoor mapping}

Figure 2 shows the daytime and nighttime street-level GEM concentrations along the major highways and streets in the city of Toronto. The data were sorted for daytime (7:00-19:00), nighttime (19:00-7:00), non-rush hours (19:00-7:00 and 11:00-16:00), rush hours (7:0011:00 and 16:00-19:00), weekday and weekend. Daytime measurements show that the higher values are more concentrated in the city core and that there were high levels of GEM $\left(>3 \mathrm{ng} \mathrm{m}^{-3}\right.$ ) along some of the streets in the downtown area. Although a smaller number of measurements were made during the nighttime, some high values observed in the downtown area, and on some highways, are in agreement with those observed during the daytime.

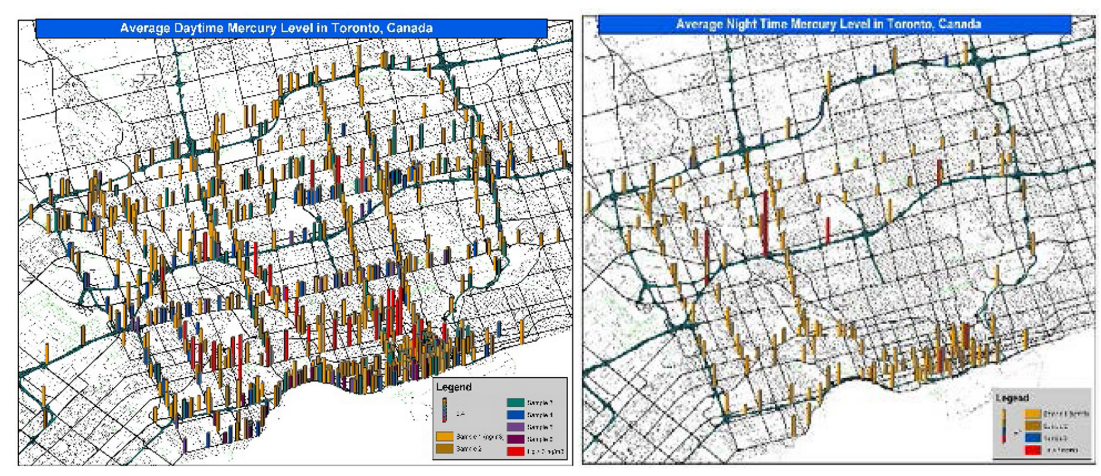

Figure 2: Daytime and nighttime street-level [GEM] in Toronto, Canada, July 2009. 
The values from the same routes varied on different days and times when the measurements were made, suggesting the effect of variable sources of $\mathrm{Hg}$ and micro-meteorological conditions. A comparison of the values with the overall driving GEM value of $1.89 \pm 0.62$ (ranging from 1.06 to 8.25$) \mathrm{ng} \mathrm{m}^{-3}$ indicates that GEM concentrations in all categories are not statistically significantly different from each other. This suggests that emission from vehicles and ground surfaces in the city was not the major sources of GEM to the urban atmosphere, as traffic volume varied between daytime and nighttime, non-rush and rush hours, weekday and weekend and temperature differed during daytime and nighttimes. The overall pedestrian level GEM $\left(1.89 \pm 0.62 \mathrm{ng} \mathrm{m}^{-3}\right)$ was in the range of GEM observed at the two rural sites near Toronto by Kellerhals et al. [16].

\subsection{GEM indoor versus outdoor}

Experiments were carried out to compare indoor and outdoor GEM at five locations in downtown Toronto, May-August 2008: a 2nd- and a 3rd-floor research laboratory, a 1st- and 3rd-floor office, and a 2nd-floor undergraduate laboratory.

The GEM values in the indoor air ranged from 15.04 to $28.54 \mathrm{ng} \mathrm{m}^{-3}$, whereas those in the outdoor air near the tested rooms ranged from 2.06 to $13.99 \mathrm{ng} \mathrm{m}^{-3}$. The indoor average GEM $\left(22.94 \pm 7.11 \mathrm{ng} \mathrm{m}^{-3}\right)$ was significantly higher than that of the outdoor $\left(9.49 \pm 2.82 \mathrm{ng} \mathrm{m}^{-3}\right)$. The GEM average in one of the research labs (2nd floor lab) was more than 13 times higher than that in the outdoor air. Higher indoor GEM values were also observed by Li et al. [17], and they might be a result of the use of $\mathrm{Hg}^{0}$ and $\mathrm{Hg}$ compounds, historically and/or currently, in such as thermometers, barometers, polarography, florescent tubes, paints, cosmetic products, scientific studies, etc. in the indoor environment. Comparing the values in the five rooms tested, GEM was higher in the laboratories than in the offices and the research laboratories (doing Hg related research) had higher GEM levels than the undergraduate student laboratory. These results indicate potential sources of $\mathrm{Hg}$ and impact of using its and $\mathrm{Hg}$ compounds on the loading of $\mathrm{Hg}$ in indoor air.

\subsection{GEM depth profile}

Depth profile of GEM around Jorgenson Hall in downtown Toronto were carried out at three levels (1.8, 4 and $59 \mathrm{~m}$ above ground), from May to July 2009. Analysis of the collected data show that the GEM values ranged from 1.25 to $1.75 \mathrm{ng} \mathrm{m}^{-3}$ (average $1.44 \pm 0.19$ ), 1.30 to $1.80 \mathrm{ng} \mathrm{m}^{-3}$ (average $1.48 \pm 0.18$ ) and 2.60 to $3.70 \mathrm{ng} \mathrm{m}^{-3}$ (average $3.09 \pm 0.47$ ) for the 1.8 , 4 and $59 \mathrm{~m}$ level, respectively. A comparison of the values observed at the three levels showed that the higher the elevation, the higher the GEM concentrations were. The values from the $1.8 \mathrm{~m}$ and $4 \mathrm{~m}$ agree well with those obtained from other locations in the city at the same height [12]. This suggests that buildings serve as sources of GEM to the atmosphere, as if GEM were emitted from the ground surface and vehicles, the GEM concentration should be, due to the dilution effect, lower at higher elevation.

\subsection{Effect of meteorological conditions}

Figure 3 describes the frequency of wind direction on the distribution of GEM for two sites 6 years apart. The GEM concentrations are the lowest in the turquoise region $\left(1-2 \mathrm{ng} \mathrm{m}^{-3}\right)$ and are representative of the background GEM concentration. Building ventilation exhausts 
KHN 2009 Aug to Oct

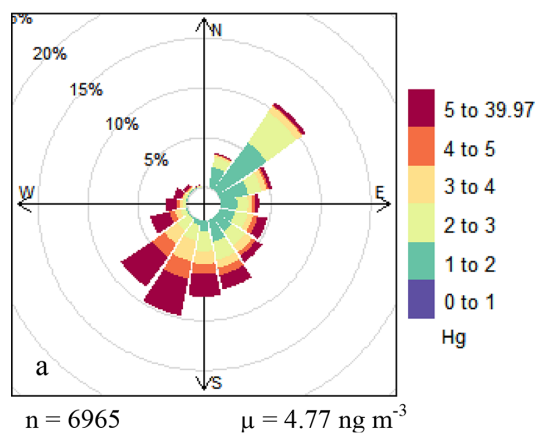

KHN 2015/16 Nov to March

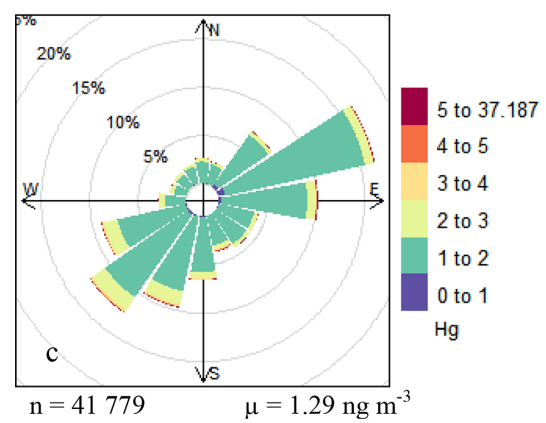

JOR 2009 Aug to Oct

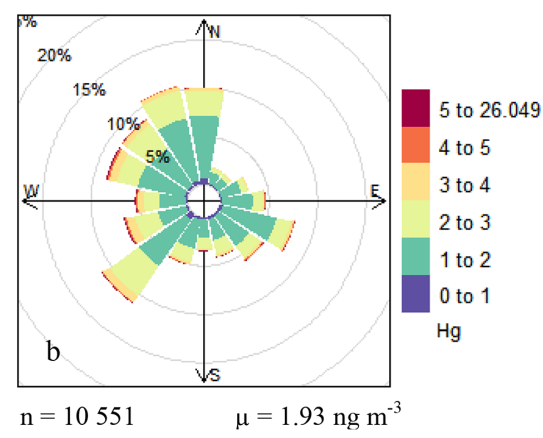

JOR 2015/16 Nov to March

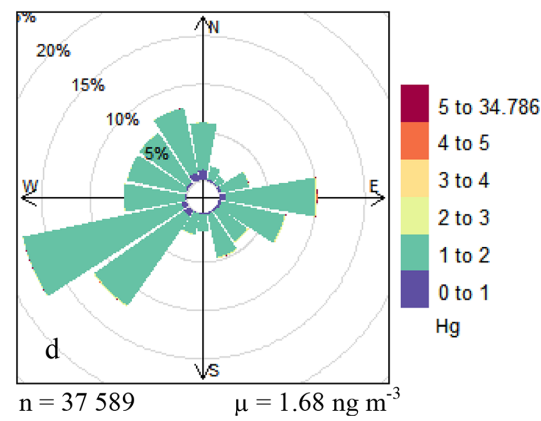

Figure 3: Pollution roses for Jorgenson Hall (JOR) and Kerr Hall North (KHN) from 2009 and $2015 / 16$. Wind sectors divided into $22.5^{\circ}$. Calm winds are assigned as wind speed $<0.2 \mathrm{~m} \mathrm{~s}^{-1}$ and are omitted from the plots.

near the air inlet at the KHE might contribute to the higher values observed at the site. The movement from high-to-low variability of $\mathrm{Hg}$ observed in 2009 vs. 2015/16 may potentially be due to initiatives taken to reduce mercury emissions. The highest concentration of GEM seems to come from the SW direction for both sites in both years. This also happens to be the direction of the downtown core. The Nanticoke Generating Station, the largest coal-fired power plant in North America, was closed down in 2013 and was also located $110 \mathrm{~km} \mathrm{SW} \mathrm{of}$ the sampling locations. The completion of a skyscraper $140 \mathrm{~m}$ to the NW direction of JOR $\left(275^{\circ}-290^{\circ}\right)$ seems to have little to no effect on wind frequency or $\mathrm{Hg}$ from that direction.

\subsection{Indoor and outdoor $\mathrm{p}-\mathrm{Hg}$}

The concentrations of outdoor total filterable p-Hg in downtown Toronto, Canada from June to December 2004 ranged from 6.7 to $149.3 \mathrm{pg} \mathrm{m}^{-3}$ and are comparable with the values reported by Lu and Schroeder [18] in metropolitan Toronto (3-91 $\left.\mathrm{pg} \mathrm{m}^{-3}\right)$ and in the Great Lakes region (1-100 $\mathrm{pg} \mathrm{m}^{-3}$ ) by Keeler [19]. Anthropogenic effects from downtown Toronto might have resulted in the high spike (up to $149.3 \mathrm{pg} \mathrm{m}^{-3}$ in 3 days) during the sampling period.

The concentrations of $\mathrm{Hg}$ associated with household settled dusts in GTA, Canada ranged from 0.01 to $8.02 \mathrm{mg} \mathrm{kg}^{-1}$ for winter 2012 and 0.07 to $10.01 \mathrm{mg} \mathrm{kg}^{-1}$ for winter 2013 . 
Geographical distribution of the $\mathrm{Hg}$ concentrations shows higher values in the city core area. The concentrations of $\mathrm{Hg}$ in indoor settled dusts collected from different indoor environments ranged from 0.42 to $1.94 \mathrm{mg} \mathrm{kg}^{-1}$ for offices, 0.04 to $1.01 \mathrm{mg} \mathrm{kg}^{-1}$ for classroom and 0.31 to $9.68 \mathrm{mg} \mathrm{kg}^{-1}$ for laboratory. The concentrations of $\mathrm{Hg}$ in laboratories were significantly higher $(p<0.05)$ than the corresponding concentrations in offices and classrooms but similar to those observed in a household. The higher values observed in laboratories and some households could be attributed to the presence of $\mathrm{Hg}$-containing particles originated from various laboratory equipment, indoor items (e.g. chemicals), worn metallic constructions, and plated and galvanized surfaces. The concentrations of $\mathrm{Hg}$ associated with indoor settled dusts observed in this study are comparable to those reported by Turner and Hefzi [20] and Rasmussen et al. [21].

\section{CONCLUSION}

The results from this study showed that, in Toronto, Canada, (1) the higher the elevation, the higher the atmospheric GEM values were in the street canyon when there is no impact from local: sources nearby; (2) GEM levels were higher indoors as compared to outdoors; (3) emission from vehicles and ground surfaces were not the major sources of GEM to the urban atmosphere. All these findings suggest that mercury used in the indoor environment serves as a source of mercury to urban atmosphere.

\section{ACKNOWLEDGEMENTS}

The Ontario Ministry of Environment (MOE) and Natural Sciences and Engineering Research Council (NSERC) of Canada for financial support.

\section{REFERENCES}

[1] Sarikaya, S., Karcioglu, O., Ay, D., Cetin, A., Aktas, C. \& Serinken, M., Acute mercury poisoning: a case report. BM C Emergency Medicine, 10(7), 2010. http://dx.doi.org/10.1186/1471-227x-10-7

[2] Bagnato, E., Allard, P., Parello, F., Aiuppa, A., Calabrese, S. \& Hammouya, G., Mercury gas emissions from La Soufriere Volcano, Guadeloupe Island (Lesser Antilles). Chemical Geology, 266(3), pp. 276-282, 2009. http://dx.doi.org/10.1016/j.chemgeo.2009.06.011

[3] Song, X., Cheng, I. \& Lu, J., Annual atmospheric mercury species in Downtown Toronto, Canada. Journal of Environmental Monitoring, 11(3), pp. 660-669, 2009. http://dx.doi.org/10.1039/b815435j

[4] Goodarzi, F., Speciation and mass-balance of mercury from pulverized coal fired power plants burning western Canadian subbituminous coals. Journal of Environmental Monitoring, 6(10), pp. 792-798, 2004. http://dx.doi.org/10.1039/b401827c

[5] Schroeder, W.H. \& Munthe, J., Atmospheric mercury - an overview. Atmospheric Environment, 32(5), pp. 809-822, 1998. http://dx.doi.org/10.1016/S1352-2310(97)00293-8

[6] Witt, M.L.I., Meheran, N., Mather, T.A., de Hoog, J.C.M. \& Pyle, D.M., Aerosol trace metals, particle morphology and total gaseous mercury in the atmosphere of Oxford, UK. Atmospheric Environment, 44(12), pp. 1524-1538, 2010. http://dx.doi.org/10.1016/j.atmosenv.2010.01.008 
[7] St. Denis, M., Song, X., Lu, J. \& Feng, F., Atmospheric gaseous elemental mercury in downtown Toronto. Atmospheric Environment, 40(21), pp. 4016-4024, 2006. http://dx.doi.org/10.1016/j.atmosenv.2005.07.078

[8] Carpi, A. \& Chen, Y. F., Gaseous elemental mercury fluxes in New York city. Water, Air, and Soil Pollution, 140(1), pp. 371-379, 2002. http://dx.doi.org/10.1023/A:1020198025725

[9] Liu, S.L., Nadim, F., Perkins, C., Carley, R.J., Hoag, G.E., Lin, Y.H. \& Chen, L.T., Atmospheric mercury monitoring survey in Beijing, China. Chemosphere, 48(1), pp. 97-107, 2002. http://dx.doi.org/10.1016/S0045-6535(02)00026-7

[10] Brown, R.J.C., Goddard, S.L., Butterfield, D.M., Brown, A.S., Robins, C.,Mustoe, C.L. $\&$ McGhee, E.A., Ten years of mercury measurement at urban and industrial air quality monitoring stations in the UK. Atmospheric Environment, 109, pp. 1-8, 2015. http://dx.doi.org/10.1016/j.atmosenv.2015.03.003

[11] Cheng, I., Lu, J. \& Song, X., Studies of potential sources that contributed to atmospheric mercury in Toronto, Canada. Atmospheric Environment, 43(39), pp. 6145-6158, 2009. http://dx.doi.org/10.1016/j.atmosenv.2009.09.008

[12] Cairns, E., Tharumakulasingam, K., Athar, M., Yousaf, M., Cheng I., Huang Y., Lu J. \& Yap D., Source, concentration, and distribution of elemental mercury in the atmosphere in Toronto, Canada. Environmental Pollution, 159(8), pp. 2001-2008, 2011. http://dx.doi.org/10.1016/j.envpol.2010.12.006

[13] National Pollutant Release Inventory (NPRI). Environment Canada Website, Canada, available at http://www.ec.gc.ca/inrp-npri/default.asp (accessed April 2016).

[14] EPA-821-R-02-019. Method 1631E: Mercury in Water by Oxidation, Purge and Trap, and Cold Vapor Atomic Fluorescence Spectrometry. August 2002.

[15] EPA-821-R-01-013. Appendix to Method 1631: Total Mercury in Tissue, Sludge, Sediment, and Soilby Acid Digestion and BrCl Oxidation. January 2001.

[16] Kellerhals, M., Beauchamp, S., Belzer, W., Blanchard, P., Froude, F., Harvey, B., McDonald, K., Pilote, M., Poissant, L., Puckett, K., Schroeder, B., Steffen, A. \& Tordon, R., Temporal and spatial variability of total gaseous mercury in Canada: results from the Canadian Atmospheric Mercury Measurement Network (CAMNet). Atmospheric Environment, 37(7), pp. 1003-1011, 2003.

http://dx.doi.org/10.1016/S1352-2310(02)00917-2

[17] Li, J., Yang, Y., Chen, H., Xiao, G. \& Wei, S., Sourcing contributions of gaseous mercury in indoor and outdoor air in China. Environmental Forensics, 11(1), pp. 154-160, 2010. http://dx.doi.org/10.1080/15275920903558919

[18] Lu, J.Y. \& Schroeder, W.H., Sampling and determination of particulate mercury in ambient air: a review. Water Air and Soil Pollution, 112(3), pp. 279-295, 1998.

[19] Keeler, G., Atmospheric Mercury in the Great Lakes Region. UMAQL Newsletter issue 1. The University of Michigan: Ann Arbor, MI, 1996.

[20] Turner, A. \& Hefzi, B., Levels and bioaccessibilities of metals in dusts from an arid environment. Water Air and Soil Pollution, 210, pp. 483-491, 2010. http://dx.doi.org/10.1007/s11270-009-0274-7

[21] Rasmussen, P.E., Subramanian, K.S. \& Jessiman, B.J., A multi-element profile of house dust in relation to exterior dust and soils in the city of Ottawa, Canada. Science of the Total Environment, 267, pp. 125-140, 2001.

http://dx.doi.org/10.1016/S0048-9697(00)00775-0 